\title{
Metafizyka światła
}

Recenzja:

Junko Theresa Mikuriya. Historia światła. Idea fotografii.

Tłum. Piotr Nowakowski. Kraków: Universitas, 2018, ss. 220

\section{Iwona Alechnowicz-Skrzypek \\ https://orcid.org/0000-0002-9074-6361}

\begin{abstract}
Obrazy istnieją dzięki światłu. Kiedy nasz daleki przodek z epoki paleolitu chciał odtworzyć ruch zwierząt namalowanych na ścianach jaskini, oświetlał je ogniem pochodni. Wszystko wówczas ożywało. Być może ta praktyka stała się inspiracją dla Platona, gdy tworzył opowieść o cieniach poruszających się przed oczami więźniów żyjących w jaskini. Cienie pojawiały się za sprawą ognia płonącego za ich plecami. Światło ognia było jednak dla Platona niczym w porównaniu ze światłem pochodzącym ze słońca, ucieleśnienia idei Dobra, stojącej na szczycie świata myśli „będącej dla wszystkiego przyczyną wszystkiego, co słuszne i piękne” jak to zostało sformułowane w VII księdze Państwa (517 B). Słońce symbolizowało dla Platona pełnię istnienia. Podobnie postrzegane było przez późniejszych myślicieli. Święty Tomasz z Akwinu widział wyraźną analogię między światłem słońca a istnieniem. Według niego, Bóg wlewa istnienie w byty, udzielając im siebie na podobieństwo tego, jak słońce oświetla powietrze, które samo nie pochłania jego promieni, a tylko je przenosi.
\end{abstract}

IWONA ALECHNOWICZ-SKRZYPEK, dr hab., prof. UO, Instytut Filozofii, Uniwersytet Opolski; adres do korespondencji: Instytut Filozofii Uniwersytetu Opolskiego, ul. Katowicka 89, 45-061 Opole; e-mail: ialechnowicz@uni.opole.pl 
Dziś światło nie ma dla nas żadnych tego rodzaju „bytowych” konotacji. Wiemy, że ma dwoistą naturę, że jest strumieniem cząstek i falą. Wiemy też, że nic nie jest od niego szybsze. Czy jesteśmy w stanie dostrzec w świetle coś więcej, niż zjawisko fizyczne? Czy łączy się z nim dla nas jakaś metafizyka? Tak, jeśli potrafi się ją wydobyć na nowo ze starych koncepcji, tak jak robi to Junko Theresa Mikuriya $\mathrm{w}$ książce Historia światła. Idea fotografii. Ta interesująca praca, to rzecz o świetle, opowieść o filozoficznych sposobach jego rozumienia i związku z obrazami; w jakimś dalekim sensie jest to opowieść o kształtowaniu się idei fotografii. Autorka tej opowieści nie skupia się jednak na technikach fotografowania, ale na tym, co leży u ich podstaw, na malowaniu światłem. Sztuka ta umożliwia powoływanie do życia obrazów za sprawą umiejętnego rzucania światła na podłoże, które je przyjmuje i w ten sposób zatrzymuje w czasie i w przestrzeni oświetlany przedmiot utrwalając jego odbicie, które nie jest niczym innym jak cieniem rzeczywistego przedmiotu.

Tak rozumiana idea fotografii stała się dla autorki Historii światła ciekawym kluczem do interpretacji znanych i mniej znanych koncepcji filozoficznych, w których daje się odnaleźć pierwiastek fotograficzny. Zarówno wybór tych koncepcji, jak i sposób ich prezentacji mają coś z procesu fotografowania. Każdy z wybranych wątków-tematów zostaje zatrzymany jak obraz w kadrze, a następnie poddany obróbce polegającej na drobiazgowej analizie rożnych jego szczegółów. Staje się w ten sposób studium przypadku zamkniętym w ramy, poza które nie wychodzi. Autorka nie nakreśla kontekstu historycznego powstania poszczególnych koncepcji i nie ukazuje logiki ich rozwoju.

$\mathrm{Na}$ początku opowieści soczewka (wyimaginowanego) obiektywu aparatu autorki skupia się na wielkim i trudnym temacie starożytności, jakim jest różnica między mniemaniem a wiedzą, odbiciem (cieniem) a oryginałem (prawdą, rzeczywistością). Następnie obiektyw jej aparatu zostaje skierowany na problem triton genos, trzeciego rodzaju, podłoża, piastunki unoszącej odbicia, na pojęciu chora, stąd przenosi się na sztukę skupiania światła Jamblicha, by ostatecznie spocząć na problemie światłoczułości jako celu doskonalenia siebie Marsilia Ficina.

Sztuka wytwarzania złudnych wyglądów to umiejętność nadawania słowom pozoru odnoszenia się do czegoś. Sztukę tę opanowali sofiści. Celem wygłaszanych przez nich mów nie było dotarcie do prawdy, lecz wytworzenie w słuchaczach określonego przekonania. Dlatego też Platon, dociekając w dialogu Sofista, 
na czym polega sztuka sofisty, zwracał uwagę na takie zjawiska i rzeczy, które jedynie coś przypominają, ale same nie są tym czymś. Sofista tworzy złudne wyglądy, czyli podobizny i wizerunki rzeczy, a nie reprezentacje samych rzeczy. Wizerunki i odbicia należą do sfery zmysłowej, natomiast oryginały, wzory rzeczy (idee) do sfery rozumowej. Gdybyśmy wzięli, jak proponuje Sokrates Glaukonowi w szóstej księdze Państwa, linię i podzielili ją na odcinki, jeden odpowiadający rodzajowi widzialnemu, drugi myślanemu, to musielibyśmy przyznać, że taka sama relacja, jaka zachodzi między obrazami a oryginałami, odpowiada relacji między mniemaniami a wiedzą (poznaniem) doxa i episteme. Przedmioty mniemań mają się do przedmiotów poznania tak, jak podobizny do swoich pierwowzorów.

Alegoria linii jest dla autorki Historii światła wizją sposobów ukazywania się prawdy (oryginału) i łączy się wprost z alegorią wyjścia więźnia z jaskini cieni ku światłu. Droga prowadzącą do prawdy jest mozolna i trudna. Wiedzie od zmysłowych obrazów (odbić, cieni) do odkrycia oryginału - idei Dobra, czyli Bytu. A idea Dobra jest jak słońce, na które można spoglądać jedynie przez chwilę, bo oślepia. W procesie fotografowania, jak twierdzi Mikuriya, jest podobnie: naciśniecie migawki aparatu na jeden moment wystawia nas na działanie światła. „Dłuższe otwarcie przysłony prowadzi do prześwietlenia kliszy i pustego zdjęcia, na którym nie pozostanie żaden ślad sfotografowanego obiektu" (s. 47).

W tajemniczym dialogu Timaios Platon opisuje stworzenie wszechświata będącego żywą istotą, która ma duszę i rozum i pomniejszych istot żywych (śmiertelnych), w tym także człowieka. Wszechświat został stworzony według wiecznego i niezmiennego wzoru. To rodzaj pierwszy „coś, co istnieje wiecznie a powstawania nie ma” (27 D). Natomiast rodzaj drugi jest przeciwieństwem pierwszego: „Zawsze powstaje a nie istnieje nigdy”(27 D). Drugiego rodzaju jest wszystko, co stworzone, co jest widzialne i dotykalne, co ujmujemy zmysłami. W stosunku do pierwowzoru ten widzialny i zmysłowy świat jest naśladowaniem pierwowzoru. Nie mogłoby być mowy o utrwaleniu wzoru w jakąś postać, gdyby nie było podłoża, które „odbija” wzór. To podłoże jest rodzajem łona. „I przyrównać wypada to, co przyjmuje do matki, pierwowzór do ojca, a ten wytwór pomiędzy nimi do potomka" (50 D). Ten trzeci rodzaj to przestrzeń (chora), w której wszystko ma swoje miejsce. W niej odciskają się wszystkie rzeczy jak obrazy na kliszy fotograficznej. Przy czym cechą chora jest to, że nadaje ona postać bytom wchodzącym do piastunki, ale sama tej formy nie przyjmuje. 
„Spogląananie na fotografię przez pryzmat Platońskiej chora niesie kilka korzyści. Po pierwsze, pozawala zauważyć, że »niewidoczność« medium nie jest tożsama z jego nieobecnością, lecz raczej stanowi jego sposób działania. Po drugie, uzasadnia podstawową tezę niniejszej książki, zgodnie z którą fotografia leży u korzeni zachodniej myśli filozoficznej. W owej nieuchwytnej obecności triton genos, jego wszechstronności i bezpostaciowej naturze niewątpliwie rozpoznajemy coś, co wydaje się mieć związek z fotografią" (s. 83-84).

Neoplatoński filozof Jamblich opanował sztukę photagogii, będącej dla autorki Historii światła permutacją pojęcia chora, które oznacza jednocześnie przyjmowanie i ustępowanie miejsca. Photagogia to sztuka przywoływania lub prowadzenia światła, gromadzenia go i skupiania, tak by umożliwić zjednoczenie z bóstwem. Dokonuje się tego w praktykach mistycznych, tak zwanych rytuałach teurgicznych, prowadzących do ekstazy umożliwiającej duszy wzlot i kontakt z boskością. Praktyki te miały charakter magiczny i wprowadzały do neoplatonizmu pierwiastek irracjonalny. Jamblich uważał, że droga do zbawienia prowadzi nie przez filozofię, ale przez teurgię (dzieło boże). Odróżniał ją od teologii (rozmowy o Bogu), która była dla niego dziedziną rozumową, gdy teurgia wykraczała poza sferę racjonalnego poznania.

Dla autorki Historii światła najważniejszym momentem tego tematu-wątku jest to, co dzieje się z teurgiem podczas rytuałów mistycznych. Mianowicie to, że teurg przyjmuje boskie światło, które zostaje niejako zapisane w jego duszy. W tym miejscu, jak twierdzi Mikuriya możemy mówić o tym, że photagogia jest photagraphią. „Przebudzony boskim blaskiem teurg działa niczym aparat fotograficzny i w akcie ekstasis chwyta to, czego nie dostrzega ludzkie oko" (s. 123).

Renesansowy myśliciel Marsilio Ficino, autor przekładu dialogów Platona na język łaciński, pisał wiele o słońcu, które było dla niego nie tylko centrum wszechświata, ale także pełnią istnienia. Duszę opisywał jako niebieskie naczynie spowite ognistą i powietrzną zasłoną oraz duchem, tworzącym trzecią warstwę złożoną ze wszystkich żywiołów. Owo niebieskie naczynie gromadzi w sobie obrazy, które są odbijane na drugiej i trzeciej zasłonie. W ten sposób może nimi władać. Mechanizm zapisu obrazów jest bardzo złożony. Nie trzeba wielkiego wysiłku, by zobaczyć w nim, jak Mikuriya, zapis fotograficzny. „Przenikaniu światła przez zasłonę towarzyszą cienie, które padają na kolejną zasłonę. Jeżeli uznamy pierwszą zasłonę za negatyw, przenikające ją światło pozostawia odciski na zasłonie drugiej 
a przeniknąwszy i przez nią - naświetla ostatnią, trzecią zasłonę. Dusza uczestniczy zatem w potrójnym procesie fotograficznym; w zapisywaniu światłem, które charakteryzuje przejście od negatywu do pozytywu, a później na powrót do negatywu stanowiącego zwieńczenie całego procesu”. (s. 164). Aby osiągnąć pełnię istnienia powinniśmy zwiększać swoją światłoczułość, umożliwiając duszy przyjmowanie boskiego światła. W traktacie De vita Ficino zaleca słoneczną dietę, umiejętność czerpania z boskiego daru życia. Dziś pewnie odczytywalibyśmy jego wskazówki dosłownie, słoneczna dieta oznaczałaby dla nas korzystanie z promieni słońca (nasłonecznianie ciała). Dla Ficina celem było takie wyćwiczenie się w przyjmowaniu boskiego światła, które umożliwi przyjęcie niezakłóconego obrazu Boga.

Gdy żyje się w świecie, w którym dominuje fotografia cyfrowa, nie ogarnia się wszystkich subtelności procesu fotograficznego w analogowym wydaniu: błysków światła przepuszczanych przez przesłonę, odbić świetlnych, ich zapisu na światłoczułym materiale. Mimo to nadal rozumie się znaczenie, jakie ma światło w fotografii. Żaden obraz nie zostanie bez niego utrwalony. A najlepiej, gdy powstaje on dzięki prawdziwemu a nie sztucznemu światłu, dzięki słońcu a nie lampie błyskowej. Choć zapis cyfrowy obrazu powstaje inaczej niż analogowy, to jego „istnienie” jest nadal efektem gry światła i cieni.

Information about Author:

IWONA ALECHNOWICZ-SKRZYPEK, associate professor, DSc, Institute of Philosophy, University of Opole; adress for correspondence: Instytut Filozofii Uniwersytetu Opolskiego, ul. Katowicka 89, PL 45-061 Opole; e-mail: ialechnowicz@uni.opole.pl 